GRASAS Y ACEITES 70 (3)

July-September 2019, e317

ISSN-L: 0017-3495

https://doi.org/10.3989/gya.0927182

\title{
Composition and characterization by GC-MS of the essential oil extracted from Nicotiana glauca Graham
}

\author{
A. Cherif ${ }^{\mathrm{a},}$, S. Ammar ${ }^{\mathrm{b}}$ and S. Boukhchina ${ }^{\mathrm{a}}$ \\ ${ }^{a}$ Department of Biology, Faculty of Sciences, University of Tunis El-Manar, Tunis 2092, Tunisia. \\ ${ }^{b}$ Department of Chemistry, Faculty of Sciences of Gabes, Erriadh city, 6072 Zrig, Tunisia. \\ Corresponding author: cherif.ammar@yahoo.com
}

Submitted: 01 September 2018; Accepted: 10 December 2018. Published online: 7 May 2019

\begin{abstract}
SUMMARY: Fresh leaves of $N$. glauca were collected from the northern region of Tunisia. The leaves were submitted to water distillation for $4 \mathrm{~h}$, using a Clevenger-type apparatus. The obtained essential oils were dried over anhydrous sodium sulphate and after filtration, stored at $4{ }^{\circ} \mathrm{C}$ until use. The chemical composition of the isolated essential oil was analyzed by gas chromatography-mass spectrometry (GC-MS). Eighteen compounds were identified: eugenol, the major compound in the essential oil, was present at a high level (58.49\%), followed by nonadecane, eugenyl acetate and tridecane, 3-methyl at 6.38; 5.57 and 5.19\%, respectively. The percentage of compounds dodecane, 2, 6, 11 trimethyl, tetradecane, docosane, tricosane and 1, 2-benzene dicarboxilic, dibutyl ester varied between 1 and $2 \%$; whereas the other compounds (including limonene, and saturated hydrocarbons) remained at low percentages, not exceeding $1 \%$. This study could be very useful for the characterization, pharmaceutical and therapeutic applications of the essential oil from $N$. glauca.
\end{abstract}

KEYWORDS: Essential oil; Eugenol; GC-MS; Hydrodistillation; N. glauca

RESUMEN: Composición y caracterización mediante GC-MS de aceite esencial extraído de Nicotiana glauca Graham. Las hojas frescas de $N$. glauca se recolectaron en la región norte de Túnez. Las hojas se sometieron a destilación en agua durante $4 \mathrm{~h}$, utilizando un aparato de destilación tipo Clevenger. Los aceites esenciales obtenidos se secaron y filtraron sobre sulfato de sodio anhidro y se almacenaron a $4{ }^{\circ} \mathrm{C}$ hasta su uso. $\mathrm{La}$ composición química del aceite esencial aislado se analizó mediante cromatografía de gases y espectrometría de masas (GC-MS). Se identificaron dieciocho compuestos: eugenol es el compuesto mayoritario $(58,49 \%)$, seguido por nonadecano, acetato de eugenilo y tridecano, 3-metilo con 6,38\%; 5,57\% y 5,19\% respectivamente. El porcentaje de los compuestos: dodecano, 2,6,11 trimetil, tetradecano, docosano, tricosano y 1,2-benceno dicarboxílico, dibutil éster varió entre 1 y $2 \%$, mientras que el resto de compuestos (incluido el limoneno e hidrocarburos saturados) permanecieron en cantidades que no superan el 1\%. Este estudio de caracterización podría ser de gran utilidad para aplicaciones farmacéuticas y terapéuticas del aceite esencial de $N$. glauca.

PALABRAS CLAVE: Aceite esencial; Eugenol; GC-MS; Hidrodestilación; N. glauca

ORCID ID: Cherif A https://orcid.org/0000-0003-4924-0120, Ammar S https://orcid.org/0000-0002-5571-9851, Boukhchina $\mathrm{S}$ https://orcid.org/0000-0003-1215-2813

Citation/Cómo citar este artículo: Cherif A, Ammar S, Boukhchina S. 2019. Composition and characterization by GC-MS of the essential oil extracted from Nicotiana glauca Graham. Grasas Aceites 70 (3), e317. https://doi. org/10.3989/gya.0927182

Copyright: (C2019 CSIC. This is an open-access article distributed under the terms of the Creative Commons Attribution 4.0 International (CC BY 4.0) License. 


\section{INTRODUCTION}

The genus Nicotiana of the family Solanaceae contains more than 40 species. Nicotiana tabacum L. and Nicotiana rustica $\mathrm{L}$. are the well-known species spread throughout the world (Pandey and Chada 1998). The leaves of these species yield tobacco and are commonly cultivated as crops. However, N. glauca, also called wild tobacco or tree tobacco, is considered the most powerful of the Nicotiana species, due to its potential for exploitation in the therapeutic field. Like all Nicotiana, it was used for many medical treatments (Watt and Breyer-Brandwijk 1962); it is used to treat burns and inflammatory diseases in some countries (Morel et al., 1998). Warmed leaves are applied to the head to relieve headache, on the throat to relieve pain and put in shoes for painful feet (Van Wyk and Gericke 2000). N. glauca is also known as a highly toxic and teratogenic plant (Panter et al., 1999). The recorded death in humans was due to poisoning by accidental ingestion of the leaves of N. glauca (Sims et al., 1999; Manoguerra and Freeman 1982). A considerable amount of work has been carried out on the metabolism of nicotine in Nicotiana species (Leete and Chedekel 1973) and other works have been conducted on the total alkaloid or nicotine content, which was determined by steam distillation and spectrophotometry. Among the alkaloids in Nicotiana, nicotine was the dominant alkaloid in the leaves of 33 species, nornicotine of 24 species, and anabasine of 2 species (N. glauca and N. debneyi); whereas in the roots of Nicotiana, anabasine predominated in 7 species of Nicotiana including N. glauca. According to (Skliar et al., 2000), results show that $N$. glauca contains 7-dehydrocholesterol, vitamin D3 and its hydroxylated metabolites. Recently, (Tabana et al., 2016) reported the anti neovascularization effect of scopoletin, an active principle extract from $N$. glauca, and its antitumorigenic activity on human tumors in xenograft models.

But, to our knowledge no information is available on the essential oil (EO) composition of $N$. glauca. Essential oils of plants and other products from secondary metabolism have been widely used in traditional medicine, food flavoring, pharmaceutical industries, perfumes and cosmetics (Bauer K, Garbe D, Surburg H. 2008; Price 1998; Satil et al., 2003) and some plant secondary metabolites were implied in the protection against herbivore attack (Kaczorowski and Markman 2016). Some biological activities of essential oils have been known for long time (Digrak et al., 1999; Dang et al., 2001; Grassmann et al., 2000). On the other hand the quantitative composition of the essential oils of many aromatic plants is greatly influenced by genotype and agronomic conditions, such as harvesting time, plant age and crop density (Marotti et al., 1996).
The present study performed on $N$. glauca, which was harvested from the northern region of Tunisia, provides the content and chemical composition of the essential oil analyzed by GC-MS.

\section{MATERIALS AND METHODS}

\subsection{Plant material}

Fresh leaves of $N$. glauca were submitted to hydro distillation for $4 \mathrm{~h}$ using a Clevenger type apparatus. Then, the extract of EO was obtained by petroleum ether extraction (Nakamura et al., 1999). The solvent was evaporated; the extract of EO was dried with anhydrous sodium sulphate. The essential oils were stored in dark glass bottles at $4{ }^{\circ} \mathrm{C}$ (Marotti et al., 1994) until analysis.

\subsection{Gas chromatography-mass spectrometry (GC-MS) analysis}

The gas chromatography-mass spectrometry analysis was carried out using a capillary column HP-5MS (30 m x 0.25i.d, film thickness: $0.25 \mathrm{~mm}$ ). The carrier gas was helium at a flow velocity of $1.2 \mathrm{ml} / \mathrm{min}$; and the splitter used a 1:5 ratio. Oven temperature was kept at $50{ }^{\circ} \mathrm{C}$ for 3 min and programmed from $50{ }^{\circ} \mathrm{C}$ to $220^{\circ} \mathrm{C}$ at a rate of $7{ }^{\circ} \mathrm{C} /$ min, then isothermal at $250^{\circ} \mathrm{C}$ for $5 \mathrm{~min}$. The injector temperature was $240{ }^{\circ} \mathrm{C}$. For GC-MS detection an electron ionization system was used. Mass spectra were taken at $70 \mathrm{eV}$. The source of impact electronic ionization was set at $230{ }^{\circ} \mathrm{C}$. The essential oil was diluted in hexane and $1 \mu \mathrm{l}$ was injected for analysis.

The identification of compounds was determined by comparison of their mass spectra with those of the database in the Wiley GC-MS Library and those in the literature (Adams 2007) where the components were listed according to their elution on the a polar column.

\section{RESULT AND DISCUSSION}

To our knowledge, no investigations have been previously performed on the chemical composition of the essential oil from $N$. glauca. The essential oil isolated from the leaves of $N$. glauca by hydro distillation (yield $<1 \%$, on dry weight basis) was analyzed by GC and GC-MS. The content and distribution of EO in the green leaves of $N$. glauca are summarized in Table 1. A total of 18 compounds representing almost $93.33 \%$ of the essential oil were characterized. Seven compounds were detected but not identified (NI) (Figure 1).

The essential oil of $N$. glauca contains a complex mixture consisting of mainly phenol, saturated, cylic and terpenic compounds (Table 1). It was dominated by eugenol $(58.49 \%)$ followed by nonadecane, 
TABLE 1. Composition of the essential oils from leaves of a Tunisian variety of Nicotiana (Nicotiana glauca Glauca).

\begin{tabular}{|c|c|c|c|c|}
\hline Pic number & $\begin{array}{l}\mathrm{Rt}^{\mathrm{a}} \\
(\mathrm{min})\end{array}$ & Compound & Chemical formula & Content \% \\
\hline 1 & 9.35 & Heptane,2,2,4,6,6-Pentamethyl & $\mathrm{C}_{12} \mathrm{H}_{26}$ & 0.50 \\
\hline 2 & 10.28 & Limonene & $\mathrm{C}_{10} \mathrm{H}_{16}$ & 0.33 \\
\hline 3 & 10.86 & $\mathrm{NI}^{\mathrm{b}}$ & & 1.84 \\
\hline 4 & 11.85 & NI & & 0.44 \\
\hline 5 & 15.61 & Heptadecane,8-methyl & $\mathrm{C}_{18} \mathrm{H}_{38}$ & 4.19 \\
\hline 6 & 16.51 & Dodecane, 2,6,11 trimethyl & $\mathrm{C}_{15} \mathrm{H}_{32}$ & 1.08 \\
\hline 7 & 17.34 & Eugenol & $\mathrm{C}_{12} \mathrm{H}_{12} \mathrm{O}_{2}$ & 58.49 \\
\hline 8 & 17.91 & Tetradecane & $\mathrm{C}_{14} \mathrm{H}_{30}$ & 1.20 \\
\hline 9 & 19.67 & Nonadecane & $\mathrm{C}_{19} \mathrm{H}_{40}$ & 6.38 \\
\hline 10 & 19.83 & Heneicosane & $\mathrm{C}_{21} \mathrm{H}_{44}$ & 0.62 \\
\hline 11 & 20.31 & Eugenyl acetate & $\mathrm{C}_{12} \mathrm{H}_{14} \mathrm{O}_{3}$ & 5.57 \\
\hline 12 & 20.61 & NI & & 0.34 \\
\hline 13 & 21.43 & Hexadecane & $\mathrm{C}_{16} \mathrm{H}_{34}$ & 0.47 \\
\hline 14 & 23.37 & NI & & 0.33 \\
\hline 15 & 23.91 & Docosane & $\mathrm{C}_{22} \mathrm{H}_{46}$ & 1.40 \\
\hline 16 & 26.44 & Tridecane,3-methyl & $\mathrm{C}_{14} \mathrm{H}_{30}$ & 5.19 \\
\hline 17 & 27.03 & Tricosane & $\mathrm{C}_{23} \mathrm{H}_{48}$ & 1.33 \\
\hline 18 & 27.09 & 1,2-Benzene dicarboxilic, dibutyl ester & $\mathrm{C}_{16} \mathrm{H}_{22} \mathrm{O}_{4}$ & 1.00 \\
\hline 19 & 29.33 & NI & & 3.17 \\
\hline 20 & 29.43 & NI & & 0.33 \\
\hline 21 & 29.86 & NI & & 0.76 \\
\hline 22 & 32.12 & Triacontane & $\mathrm{C}_{30} \mathrm{H}_{62}$ & 2.62 \\
\hline 23 & 32.74 & Hexacosane & $\mathrm{C}_{26} \mathrm{H}_{54}$ & 0.78 \\
\hline 24 & 32.82 & Eicosane & $\mathrm{C}_{20} \mathrm{H}_{42}$ & 0.70 \\
\hline 25 & 34.59 & Pentacosane & $\mathrm{C}_{25} \mathrm{H}_{52}$ & 0.95 \\
\hline
\end{tabular}

a: Retention Time, b: Non Identified

eugenyl acetate and tridecane,3-methyl at 6.38\%; $5.57 \%$ and $5.19 \%$, respectively. These compounds were considered as major in the EO; while the percentages of dodecane,2,6,11 trimethyl, tetradecane, docosane, tricosane and 1,2-benzene dicarboxilic, dibutyl ester varied between 1 and $2 \%$. The remaining compounds (included limonene and saturated hydrocarbons $(\mathrm{SH})$ ) were only present in small percentage $(<1 \%)$, with the exception of triacontane, which was found at $2.62 \%$.

Compared to our results, the same number of compounds was found in the essential oils of $N$. rustica; whereas twenty-seven EO were detected in $N$. forgetiana (Schlotzhauer et al., 1995). According to Popova et al., (2017) nineteen compounds in the essential oil of the leaves of $N$. alata were characterized, but different compounds in each species were detected by GC-MS. Our results showed the presence of 10 n-alkanes (saturated hydrocarbons). However, compared to the above authors, only two saturated hydrocarbons (tricosane and pentacosane) were identified in $N$. rustica and five $\mathrm{SH}$ were identified in $N$. forgetiana. The percentage of the EO composition was very different in the same genus. In fact, the percentages of tricosane in our study on $N$. glauca and in others on $N$. rustica and $N$. forgetiana were 1.33, 0.38, and $8.16 \%$, respectively. In our research, the major compound was eugenol $(58.49 \%)$. In contrast, phytol $(38.82-48.53 \%)$ was the dominant compound in N. alata; nicotine $(25.92 \%)$ and pentacosane $(8.35 \%)$ were the major compounds in N. rustica and N. forgetiana, respectively.

The same major compounds in the EO can be found in different plants. Eugenol, the major component of the oil of $N$. glauca, was likewise present in a higher quantity $(72-90 \%)$ in the EO fraction of Syzygium aromaticum (Bao et al., 2012). This component varied between 3.1 and $21.1 \%$ in the essential oil of Ocimum basilicum cultivated in Turkey, and in the same species the percentage of methyl eugenol was detected at a high level (> 34\%) (Telci et al., 2006). However, the chemical composition of essential oils was specific to each species, regardless of its origin. In fact, the results showed that the EO of $N$. glauca (Tunisia) has a specific chemical 


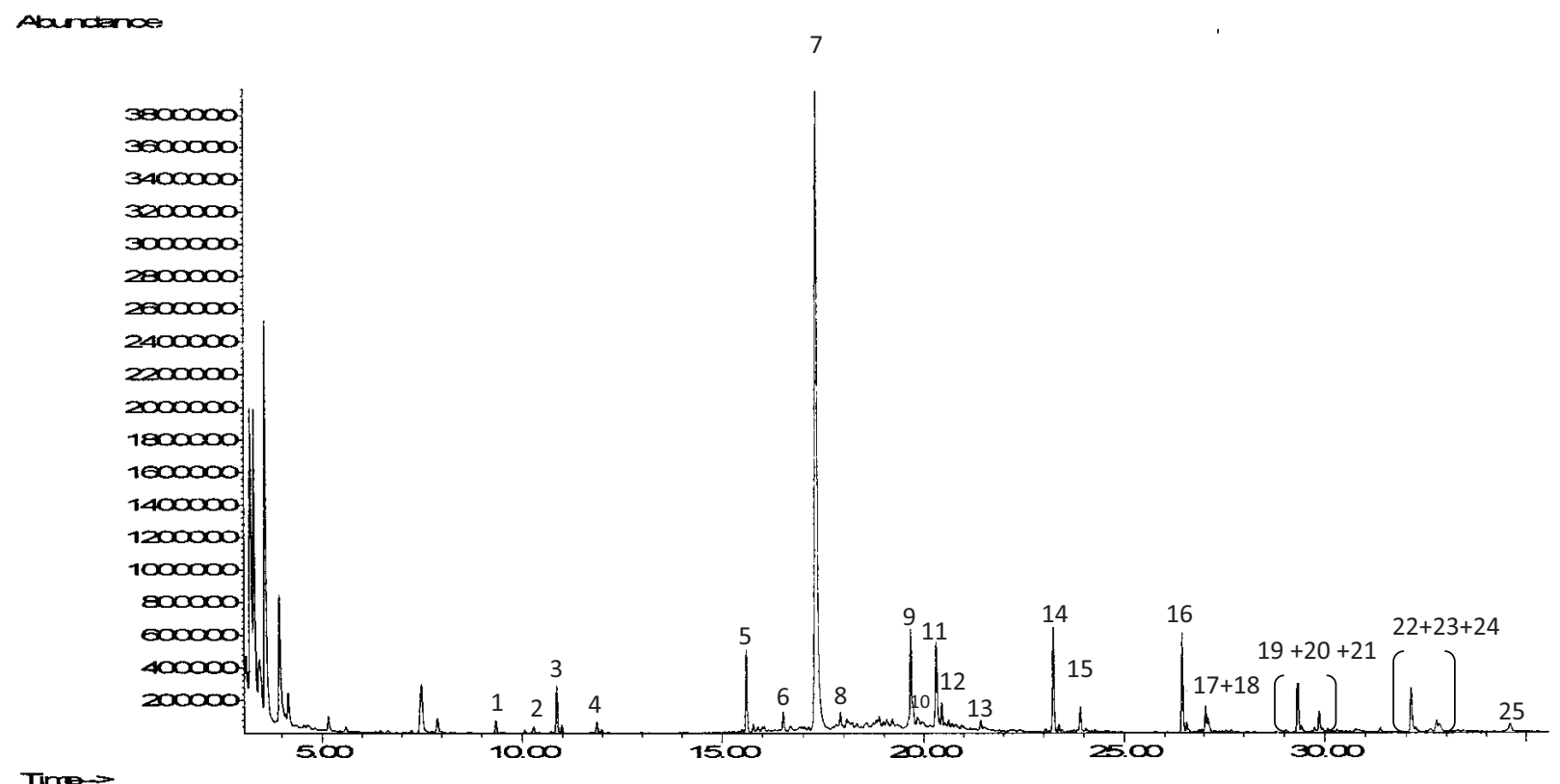

FIGURE 1. Total ion chromatogram of essential oil from Nicotiana glauca Graham. (For compound names see Table 1).

composition compared to $N$. rustica, $N$. forgetiana (Oxford) and N. alata (Bulgaria). This information could be used as a fingerprint for this species.

\section{CONCLUSION}

The content and distribution of EO in the green leaves of $N$. glauca are provided in this work. Eugenol was the dominant EO followed by nonadecane, eugenyl acetate and tridecane,3-methyl. In general, the $N$. glauca oil was characterized by a high percentage of the saturated hydrocarbons; while heneicosane, limonene and hexadecane were the minor constituents $(<0.5 \%$ for each compound) in the EO. This plant is therefore considered a potential source of eugenol $(58.49 \%)$ and due to this high eugenol content, it can be exploited for medicinal purposes and other applications.

\section{ACKNOWLEDGMENTS}

The authors would like to thank the Arid Regions Institute (IRA) personnel (Medenine, Tunisia) for the availability of the GC-MS used to carry out this research.

\section{DECLARATION OF FUNDING SOURCE AND CONFLICT OF INTEREST}

This research did not receive any specific grant from funding agencies in the public, commercial, or not-for-profit sectors.
The authors declare that they have no conflict of interest.

\section{REFERENCES}

Adams RP. 2007. Identification of Essential Oil Components by Gas Chromatography/Mass Spectrometry, 4th Edition., Allured Pub Corp, Carol Stream, Ill.

Bao LM et al. 2012. Hydrolysable tannins isolated from Syzygium aromaticum: Structure of a new C-Glucosidic ellagitannin and spectral features of tannins with a tergalloyl group. Heterocycles 85, 365-381. https://doi.org/10.3987/ COM-11-12392

Bauer K, Garbe D, Surburg H. 2008. Common Fragrance and Flavor Materials: Preparation, Properties and Uses, 3rd Edition. Wiley.com. Available at: https://www.wiley.com/ en-us/Common+Fragrance+and+Flavor+Materials $\% 3$ A+Preparation $\% 2 \mathrm{C}+$ Properties +and +Uses $\% 2 \mathrm{C}+3 \mathrm{rd}+$ Edition-p-9783527612376 [Accessed July 3, 2018].

Dang MN et al. 2001. Antioxidant activity of essential oils from various spices. Nahr. 45, 64 66. https://doi.org/10.1002/15213803(20010101)45:1<64::AID-FOOD64>3.0.CO;2-U

Digrak M et al. 1999. Antibacterial and Antifungal Effects of Various Commercial Plant Extracts. Pharm. Biol. 37, 216-220. https://doi.org/10.1076/phbi.37.3.216.6307

Grassmann J et al. 2000. Antioxidant properties of essential oils. Possible explanations for their anti-inflammatory effects. Arzneimittelforschung 50, 135-139.

Kaczorowski RL, Markman S. 2016. Nectar alkaloids of tree tobacco can reduce Palestine sunbird foraging performance in a colour discrimination task. Anim. Behav. 119, 59-68.

Leete E, Chedekel MR. 1973. Metabolism of nicotine in Nicotiana glauca. Phytochemistry 13, 1853-1859. https:// doi.org/10.1016/0031-9422(74)85101-0

Manoguerra AS, Freeman D. 1982. Acute Poisoning from the Ingestion of Nicotiana glauca. J. Toxicol. Clin. Toxicol. 19, 861-864. https://doi.org/10.3109/15563658208992520

Marotti M et al. 1994. Effects of planting time and mineral fertilization on peppermint (Mentha $x$ Piperita L.) essential oil composition and its biological activity. Flavour Fragr. J. 9, 125-129. https://doi.org/10.1002/ffj.2730090307 
Marotti M, Piccaglia R, Giovanelli E. 1996. Differences in Essential Oil Composition of Basil (Ocimum basilicum L.) Italian Cultivars Related to Morphological Characteristics. J. Agric. Food Chem. 44, 3926-3929. https://doi.org/10.1021/ jf9601067

Morel AF et al. 1998. A new amide from Nicotiana glauca. Planta Med. 64, 284-285.

Nakamura CV et al. 1999. Antibacterial activity of Ocimum gratissimum L. essential oil. Mem. Inst. Oswaldo Cruz 94, 675678. https://doi.org/10.1590/S0074-02761999000500022

Pandey SN, Chada A. 1998. A Textbook of Botany: Plant Anatomy and Economic Botany Vol 3 10th edition., Sangam Books Ltd, New Delhi.

Panter KE, James LF, Gardner DR. 1999. Lupines, poisonhemlock and Nicotiana spp: toxicity and teratogenicity in livestock. J. Nat. Toxins 8, 117-134.

Popova V et al. 2017. Biologically Active and Volatile Compounds in Leaves and Extracts of Nicotiana alata Link \& Otto from Bulgaria. J. Pharm. Sci. Res. 9, 2045-2051.

Price S. 1998. Aromatherapy Workbook: Understanding Essential Oils - From Plant to Bottle, Thorsons, London.

Satil F, Azcan N, Baser KHC. 2003. Fatty Acid Composition of Pistachio Nuts in Turkey. Chem. Nat. Compd. 39, 322-324. https://doi.org/10.1023/B:CONC.0000003408.63300.b5
Schlotzhauer WS et al. 1995. Comparison of the Volatile Flower Oils of Nicotiana rustica and N. forgetiana. J. Essent. Oil Res. 7, 265-269. https://doi.org/10.1080/10412905.1995.9698517

Sims DN, James R, Christensen T. 1999. Another death due to ingestion of Nicotiana glauca. J. Forensic Sci. 44, 447-449.

Skliar null et al. 2000. Nicotiana glauca: another plant species containing vitamin D(3) metabolites. Plant Sci. Int. J. Exp. Plant Biol. 156, 193-199.

Tabana YM et al. 2016. Scopoletin, an active principle of tree tobacco (Nicotiana glauca) inhibits human tumor vascularization in xenograft models and modulates ERK1, VEGF-A, and FGF-2 in computer model. Microvasc. Res. 107, 17-33. https://doi.org/10.1016/j.mvr.2016.04.009

Telci I et al. 2006. Variability in essential oil composition of Turkish basils (Ocimum basilicum L.). Biochem. Syst. Ecol. 34, 489-497. https://doi.org/10.1016/j.bse.2006.01.009

Van Wyk B-E, Gericke N. 2000. People's plants: A guide to useful plants of Southern Africa., Briza Publications.

Watt J, Breyer-Brandwijk M. 1962. The Medicinal and Poisonous Plants of Southern and Eastern Africa Auction \#28 | AntiquarianAuctions.com. Available at: https://antiquarianauctions.com/lots/the-medicinal-andpoisonous-plants-of-southern-and-eastern-africa-11373 [Accessed July 2, 2018]. 